Jurnal Dinamika Ekonomi Syariah

Vol 08, No. 01, 2021, hlm.48-62

http://ejurnal.iaipd-nganjuk.ac.id/index.php/es/index

ISSN-e 2715-7334 | ISSN-P 2654-3567

\title{
Analisis Hukum Islam Terhadap Strategi Pemasaran Usaha Konveksi CV. Nuratina Collection dalam Menghadapi Persaingan Bisnis di Era Industri 4.0
}

\author{
Juni Iswanto ${ }^{1}$, Puji Winarko², Zainatun Munawarah ${ }^{3}$ \\ ${ }^{1}$ Institut Agama Islam Pangeran Diponegoro Nganjuk. Jl.Wilis Kramat,Nganjuk. \\ ${ }^{2}$ Institut Agama Islam Pangeran Diponegoro Nganjuk. Jl.Wilis Kramat,Nganjuk. \\ 3Institut Agama Islam Pangeran Diponegoro Nganjuk. Jl.Wilis Kramat,Nganjuk. \\ E-mail: juniiswanto@,iaipd-nganjuk.ac.id
}

Received:Januari 2021

Revised:Februari 2021

Accepted:Februari 2021

\begin{abstract}
:
In the practice of muamalah and Islamic economics, buying and selling (al-bai ') is a form of contract that is very important for the continuity of human life, this is because humans are not separated from daily needs (emergency) or needs that are hajiah in nature. and tahsiniah. In modern life, sometimes a person or group has a request or desire to make goods that are not on the market according to their taste, such as clothes. Items like this are usually ordered to be made to people who are experts in their fields. In the industrial era 4.0 like this, marketing can also be very relied on by means of the digital world, the rapid development of information technology, which can be seen in the massive use of the internet network, has also boosted the public's need to always conduct trade transactions using the internet network. The problem in this research is how the marketing strategy of $C V$. Nuratina Collection in the face of business competition in terms of Islamic law. The research objective is to determine the marketing strategy of CV convection business. Nuratina Collection in facing business competition in terms of Islamic law. The research method used is descriptive research and with a qualitative approach. Primary data sources are owners and employees and secondary data sources are documentation and archives. Data collection techniques and instruments were observation, interview, documentation. While the data analysis technique is making direct observations by relying on the imagination, enthusiasm, and creativity of the researcher. Test the validity of the researcher data using the extension of the researcher participation and observation persistence. The result of this research is $C V$ convection business marketing strategy. Nuratina Collection in facing business competition in Industry 4.0 in terms of Islamic law.
\end{abstract}

Keywords: Islamic Law, Marketing Strategy, Business Competition, Era 4.0

\begin{abstract}
:
Dalam praktik muamalah dan ekonomi Islam, jual beli (al-bai') adalah salah satu bentuk akad yang sangat penting bagi kelangsungan kehidupan manusia, hal ini disebabkan karena manusia setiap harinya tidak terlepas oleh kebutuhan yang bersifat pokok (darurat) maupun kebutuhan yang bersifat hajiah serta tahsiniah. Kehidupan modern ini terkadang seseorang ataupun kelompok memiliki permintaan atau kehendak untuk dibuatkan barang yang belum ada di pasaran yang sesuai dengan seleranya, seperti pakaian. Barang seperti ini biasanya di pesan untuk dibuat kepada orang yang ahli dalam bidangnya. Di era industri 4.0 seperti ini pemasaran juga bisa sangat diandalkan dengan cara dunia digital, pesatnya perkembangan teknologi informasi, yang terlihat pada masifnya penggunaan jaringan internet, turut mendongkrak kebutuhan masyarakat untuk senantiasa melakukan transaksi dagang menggunakan jaringan internet. Permasalahan dalam penelitian ini adalah bagaimana strategi pemasaran usaha konveksi CV. Nuratina Collection dalam menghadapi persaingan bisnis ditinjau dari hukum Islam. Adapun tujuan penelitiannya adalah untuk mengetahui strategi pemasaran usaha konveksi CV. Nuratina Collection dalam menghadapi persaingan bisnis ditinjau dari hukum Islam. Metode penelitian yang digunakan adalah penelitian deskriptif dan dengan pendekatan kualitatif. Sumber data primer adalah pemilik dan pegawai dan sumber data sekunder berupa dokumentasi, serta arsip-arsip. Teknik dan instrumen pengumpulan data berupa observasi, wawancara, dokumentasi. Sedangkan teknik analisis data yaitu melakukan pengamatan secara langsung degan mengandalkan daya imajinasi, antusias, dan daya kreasi peneliti. Uji keabsahan data peneliti menggunakan perpanjangan keikutsertaan peneliti dan ketekunan pengamatan. Hasil dari
\end{abstract}


penelitian ini adalah strategi pemasaran usaha konveksi CV. Nuratina Collection dalam menghadapi persaingan bisnis diera Industri 4.0 ditinjau dari hukum Islam.

Kata Kunci: Hukum Islam, Strategi Pemasaran, Persaingan Bisnis, Era 4.0.

\section{PENDAHULUAN}

Dalam praktik muamalah dan ekonomi Islam, jual beli (al-bai') adalah salah satu bentuk akad yang sangat penting bagi kelangsungan kehidupan manusia, hal ini disebabkan karena manusia setiap harinya tidak terlepas oleh kebutuhan yang bersifat pokok (darurat) maupun kebutuhan yang bersifat hajiah serta tahsiniah. Kehidupan modern ini terkadang seseorang ataupun kelompok memiliki permintaan atau kehendak untuk dibuatkan barang yang belum ada di pasaran yang sesuai dengan seleranya, seperti pakaian. Barang seperti ini biasanya di pesan untuk dibuat kepada orang yang ahli dalam bidangnya. Manusia adalah sebaik-baiknya khalifah Allah di muka bumi, maka wajib tolongmenolong dan saling membantu dalam melaksanakan kegiatan ekonomi dengan yang bertujuan untuk beribadah kepada Allah SWT. Selain itu manusia diperintahkan agar percaya kepada hari kiamat, sebab dalam tingkah laku ekonomi akan terkendali karena pasti semua perbuatan akan dipertanggungjawabkan oleh Allah SWT. ${ }^{1}$

Di zaman yang modern ini perkembangan di dunia usaha berjalan dengan begitu ketat dan situasi bisnis yang semakin kompetitif menimbulkan persaingan yang begitu tajam. Banyaknya perusahaan yang didirikan menjadi faktor pemicu tingkat persaingan di dunia bisnis menjadi semakin tajam.

Dalam memenangkan persaingan tersebut dibutuhkan berbagai cara salah satunya yaitu promosi di sektor pemasaran. Dengan tujuan untuk meningkatkan volume penjualan sehingga menghasilkan laba yang terus meningkat dan perusahaan dapat mencapai kesejahteraan. Meningkatkan kepuasan pelanggan dengan melalui produk berkualitas harus dioptimalkan dengan baik. Selain itu ketepatan waktu dan tempat. pengiriman juga sangat diperlukan supaya customer merasa puas dengan kinerja perusahaan kita.

Salah satu bidang yang terpenting di dalam menghadapi persaingan industri adalah pada sektor pemasaran. Pemasaran adalah pemenuhan kebutuhan dan keinginan penjualan produk atau jasa. Pemasaran bukanlah sekedar menciptakan suatu produk dan menjualnya, pemasaran lebih terhadap pemenuhan kebutuhan dan keinginan. Pahami apa yang dibutuhkan dan diinginkan seseorang dan memberikan itu kepada mereka dengan cara yang lebih baik dan lebih murah dari para pesaing. ${ }^{2}$ Adapun pemasaran dari suatu produk mencakup kegiatan menyelidiki dan mengetahui apa yang diinginkan oleh konsumen nya, perencanaan dan pengembangan suatu produk dan jasa yang akan memenuhi keinginan tersebut, dan membuat suatu keputusan untuk menentukan harga, promosi, dan pendistribusian barang maupun jasa guna memenuhi apa yang diinginkan oleh konsumen nya. Karena itu strategi pemasaran sangatlah penting dalam keberhasilan suatu perusahaan. Pemasaran mempunyai peran yang sangat penting apabila produk dah harga telah ditetapkan oleh perusahaan. Dengan penggunaan promosi yang tepat maka diharapkan produk yang akan dihasilkan oleh perusahaan dapat dikenal oleh masyarakat. Karena itu strategi dalam melaksanakan pemasaran harus dilakukan secara tepat.

Promosi adalah suatu cara atau kegiatan memperkenalkan produk barang atau jasa kepada calon pembeli dengan berbagai cara yang bisa menarik perhatian pembeli dan dalam hal ini berpengaruh terhadap peningkatan volume penjualan.

Di era industri 4.0 seperti ini pemasaran juga bisa sangat diandalkan dengan cara dunia digital, pesatnya perkembangan teknologi informasi, yang terlihat pada masif nya penggunaan jaringan internet, turut mendongkrak kebutuhan masyarakat untuk senantiasa melakukan transaksi dagang menggunakan jaringan internet. Berbagai aspek transaksi yang tergolong dalam proses interaksi bisnis

${ }^{1}$ Abdul Manan, Hukum Ekonomi Syariah. Jakarta: Kencana, 2014, 10.

${ }^{2}$ Ika Yunia Fauzia, Etia Bisnis Dalam Islam edisi pertama. Jakarta: Kenca Prenada Media Group, $2013,5$. 
konvensional berubah dengan cepat ketika perdagangan secara face-to-face mulai digantikan dengan perdagangan online berbasis internet. Transaksi komersil (profit transaction) yang biasanya dilakukan secara konvensional, telah bergeser ke arah yang lebih dinamis melalui penggunaan jaringan internet. Transaksi melalui jaringan internet diyakini memudahkan pegiat ekonomi dalam melakukan transaksi serta menjadi solusi dalam terbatasnya ruang dan waktu. Bahkan, dalam hal lain bentuk transaksi ini dapat terjadi secara bersamaan tanpa harus ada pertemuan langsung dengan hitungan waktu yang begitu cepat.

Sekarang banyak perusahan yang melakukan pemasaran melalui teknologi contohnya melakukan penjualan dengan cara online. Banyak masyarakat melakukan transaksi online untuk membeli barang, tetapi dalam melakukan sistem teknologi ini juga ada aturan dari pemerintah yang tertera dalam UU ITE (Informasi Teknologi Dan Transaksi Elektronik) Nomor 11 tahun 2008 yang mengatur tentang informasi serta transaksi elektronik atau teknologi informasi secara umum.

Dalam Islam jual beli online disebut Salam, yaitu jual beli barang yang disifati (dengan kriteria tertentu/aspek tertentu) dalam tanggungan (penjual) dengan pembayaran kontan di majelis akad. Dengan istilah lain bai'us salam adalah akad pemesanan suatu barang dengan kriteria yang telah disepakati dan dengan pembayaran tunai pada saat akad berlangsung. Dalam islam juga diajarkan bahwasanya dalam menginformasikan segala sesuatu kepada orang lain kita harus jujur sesuai dengan kenyataan nya, karena dengan demikian kita akan merasa lega dan orang lain akan merasa puas dengan hal itu bila kita terapkan dalam strategi promosi kita.

Produk bermanfaat apabila proses produksinya benar dan baik. Ada pun metode yang dapat digunakan agar proses produksi benar dan baik dalam menjelaskan manfaat produk, nampaknya peranan data dan fakta sangat penting. Bahkan sering data dan fakta jauh lebih berpengaruh dibanding penjelasan. Produksi pakaian atau usaha konveksi adalah usaha mengolah bahan kain yaitu bahan mentah untuk dijadikan pakaian/barang jadi. di mana barang jadi tersebut adalah berupa baju, kaos, celana, dan lain-lain. Produsen beserta para karyawannya berusaha mengolah kain yang semula tidak dapat digunakan untuk pakaian, kini dijadikan pakaian dengan berbagai macam bentuk yang bagus dan layak untuk dijual.

Dalam persaingan kita mengenal istilah "pesaing" yaitu perusahaan yang menghasilkan atau menjual barang atau jasa atau mirip dengan produk yang kita tawarkan. Pesaing suatu perusahaan dapat dikategorikan pesaing yang kuat dan pesaing yang lemah atau ada pesaing yang dekat yang memiliki produk yang sama atau memiliki produk yang mirip. 3 Jadi dapat dikatakan persaingan adalah keadaan ketika organisasi berperang atau berlomba untuk mencapai hasil atau tujuan yang diinginkan. Perspektif industri mengidentifikasi pesaing sebagai organisasi yang membuat produk atau jasa yang sama. Menurut perspektif pemasaran, pesaing adalah organisasi yang mampu memenuhi kebutuhan konsumen yang sama.

Terkait dengan usaha konveksi, perusahaan konveksi Nuratina Collection merupakan salah satu perusahaan yang berada di kota Nganjuk. Lokasi Outlet perusahaan ini berada di jalan Dr. Soetomo VI no 7 B Kelurahan Bogo Kecamatan Nganjuk kabupaten Nganjuk. Lokasi yang sangat strategis untuk pemasaran karena berada di tengah-tengah kota Ngajuk dan mudah untuk dilewati transportasi baik roda dua maupun roda empat. Sehingga mudah jika ada customer dari luar kota yang ingin datang langsung ke perusahaan ini.

Perusahaan Nuratina Collection ini sangat bagus perkembangannya, sekalipun masih berkembang menengah tapi perusahaan ini cukup banyak menyerap tenaga kerja di sekitarnya, jadi perusahaan ini cukup bisa diandalkan perkembangan perekonomiannya. Selain itu perusahaan ini masih sangat kreatif dalam hal pemasaran, tidak hanya toko offline tetapi juga mengikuti perkembangan teknologi yakni menggunakan pemasaran sekaligus penjualan secara online. terbukti sudah banyak pengiriman hingga di luar pulau Jawa seperti Sumatra, Sulawesi, Kalimantan sampai Papua. Untuk menjaga kualitas produksi yang handal, promosi yang bagus sangat diperlukan 
manajemen kerja yang profesional untuk mendatangkan kesejahteraan bagi berbagai pihak. Tentu saja yang sesuai dengan Syari'ah dan tidak bertentangan dengan ajaran Islam. Untuk itu penulis ingin meneliti lebih lanjut untuk dijadikan sebuah karya ilmiah. Khususnya pada strategi promosi yang dilakukan oleh pengusaha konveksi di Nganjuk tersebut.

Oleh karena itu peneliti sangat tertarik untuk mengadakan penelitian lebih jauh pada usaha konveksi yang ada di Nganjuk tersebut, sehingga peneliti mengkaji tentang Analisis Hukum Islam terhadap Strategi Pemasaran Usaha Konveksi CV. Nuratina Collection Dalam Menghadapi Persaingan Bisnis di Era Industri 4.0 dengan fokus penelitian bagaimana strategi pemasaran usaha konveksi CV. Nuratina Collection dalam menghadapi persaingan bisnis ditinjau dari hukum Islam?, Tujuan dari dilakukannya penelitian ini adalah untuk Mengetahui Strategi Pemasaran usaha konveksi CV. Nuratina Collection dalam menghadapi persaingan bisnis ditinjau dari hukum islam.

\section{METODE PENELITIAN}

Dalam penelitian ini penulis menggunakan pendekatan penelitian kualitatif. Penelitian kualitatif ditunjukkan untuk memahami fenomena-fenomena sosial dari sudut atau perspektif partisipan. Partisipan adalah orang-orang yang diajak berwawancara, diobservasi, diminta pemberian data, pendapat, pemikiran, dan persepsi. Sedangkan jenis penelitian menggunakan penelitian deskriptif (descriptive research). Yaitu ditujukan untuk mendeskripsikan suatu keadaan fenomena-fenomena apa adanya. dalam penelitian ini, peneliti tidak melakukan manipulasi atau perlakuan-perlakuan tertentu terhadap obyek penelitian, semua kegiatan atau peristiwa berjalan seperti apa adanya. ${ }^{4}$

Data dalam penelitian ini terdiri dari dua jenis yaitu data primer dan sekunder. Pengambilan data dilakukan dengan teknik wawancara, observasi, dan dokumentasi. Sedangkan teknik analisis data yang digunakan analisis data deskriptif kualitatif dengan menggunakan proses berpikir deduktif. Kehadiran peneliti di tempat penelitian mutlak diperlukan sebagai instrumen utama. Instrumen penelitian adalah semua alat yang digunakan untuk mengumpulkan, memeriksa, menyelidiki suatu masalah dalam penelitian. Peneliti bertindak sebagai instrumen utama yaitu peneliti bertindak sebagai pengumpul data, penganalisis dan pelapor hasil. sedangkan instrumen selain manusia bersifat sebagai pendukung.

Penelitian dilakukan di Perusahaan Nuratina Collection Jl. Dr. Soetomo VI no 7 B kel. Bogo Kecamatan Nganjuk Kabupaten Nganjuk. Dapat dilihat dari jumlah orderan yang mengalami peningkatan setiap tahunnya. Selain itu, perusahaan mempunyai inovasi yang lebih, terbukti meskipun perusahaan ini industri kecil, namun tetap berupaya memperhatikan kualitas produksi, yaitu dengan cara pemilihan kualitas bahan yang terbaik sehingga konsumen merasa puas dengan hasilnya. Sumber data primer didapatkan dari wawancara, sedangkan sumber data sekunder didapat dari hasil observasi dan dokumentasi. Sumber data dalam penelitian ini adalah pemilik perusahaan yang sekaligus sebagai subjek penelitian.

Teknik pengumpulan data menggunakan wawancara, observasi dan dokumentasi. Sedangkan teknik analisis data, peneliti melakukan pengamatan secara langsung dengan mengandalkan daya imajinasi, antusias, dan daya kreasi peneliti dalam proses yang disebut adalah untuk menemukan makna peristiwa yang ada pada objek penelitian dan menginterpretasikan makna dari hal yang diteliti. Uji Keabsahan Data dapat dilakukan oleh peneliti sendiri sebagai partisipan, bisa menggunakan data dari hasil wawancara dan juga data yang sudah dikumpulkan (foto, surat, maupun catatan khusus), apakah sesuai hasil wawancara dan hasil pengumpulan datanya. Jika sesuai maka data tersebut dianggap absah.

${ }^{4}$ Sudaryono, Metodologi Penelitian. Jakarta: Rajawali Pers, 2017.82. 


\section{HASIL DAN PEMBAHASAN}

\section{Hasil penelitian}

\section{Strategi Pemasaran Usaha Konveksi CV. Nuratina Collection Nganjuk Dalam Menghadapi Persaingan Bisnis di Era Indusri 4.0}

Nuratina Collection merupakan salah satu konveksi yang ada di Kelurahan Bogo Kecamatan Nganjuk Kabupaten Nganjuk. Konveksi ini merupakan konveksi yang cukup maju dan pesat dalam perkembangan. Hal tersebut dapat dilihat dalam jumlah karyawan serta pemesan pakaian. yang berasal dari beberapa wilayah khususnya dari luar kota.

Seperti yang telah dijelaskan pada pembahasan sebelumnya bahwa tidak hanya satu jenis saja produk yang dihasilkan oleh Nuratina Collection, melainkan ada beberapa jenis produk yang dihasilkan oleh konveksi ini. Yaitu manset, baju muslimah dan menyusui, Aksesoris dan produk-produk yang lain.

Adapun letak konveksi ini sangat strategis sehingga mudah untuk dijangkau oleh para konsumen. Bahkan konsumen tidak hanya datang dalam kota saja, akan tetapi cukup banyak konsumen yang datang dari luar kota seperti halnya kota Kediri, Kota Blitar, Kabupaten Trenggalek dan masih banyak lagi. Bahkan konsumen yang berasal dari luar pulau pun juga ikut berdatangan untuk memesan produk yang dihasilkan oleh konveksi ini. Sebagaimana yang telah dijelaskan oleh pengusaha konveksi ini: ${ }^{5}$

"Konsumen yang membeli di konveksi ini cukup banyak dan itu merupakan salah satu keuntungan yang kita peroleh. Karena dengan banyaknya konsumen, maka ini sebagai bukti bahwa perusahaan kami sudah cukup dikenal oleh masyarakat tidak hanya di Kota Nganjuk melainkan sampai luar kota seperti Kota Blitar, Kota Kediri, Kota Surabaya dan kota-kota lain. Bahkan kami pun juga melayani orang yang berasal dari luar pulau seperti Sumatra, Kalimantan, Jakarta, Timor Leste dan wilayah lain di Indonesia."

Dengan banyaknya konsumen yang beli, maka hal ini merupakan sesuatu yang sangat bagus dan mendukung Nuratina Collection untuk membuka Reseller di banyak tempat dan membuka peluang usaha Online untuk yang lainnya. Sehingga perusahaan lebih dikenal masyarakat dengan baik serta semakin banyak konsumen yang beli. Tentunya dengan membuka Reseller di tempat lain maka akan mengalami penambahan jumlah pemasukan di dalam perusahaan ini.

Tentunya perkembangan Nuratina Collection seperti saat ini, tidak dilakukan dengan cara yang mudah. Jatuh bangun pengusaha konveksi ini untuk melakukan pengembangan konveksi supaya konveksi ini lebih mengalami kemajuan. Akan tetapi, kegagalan pengusaha Nuratina Collection yang dialami tersebut sebagai cambuk bagi dirinya untuk tetap berusaha demi mendapatkan sesuatu yang maksimal.

Begitupun dengan banyaknya konsumen yang ada sekarang. Yang pasti banyaknya konsumen yang membeli produk seperti sekarang ini, tidak didapatkan begitu saja oleh Nuratina Collection. Dengan mengeluarkan produk yang sesuai dengan selera konsumen serta pelayanan yang baik merupakan usaha yang paling penting untuk dilakukan oleh konveksi ini. Sebagaimana yang telah dijelaskan oleh salah satu karyawan di Nuratina Collection: ${ }^{6}$

"Dalam menarik perhatian konsumen serta konsumen tetap percaya dengan produk yang kami hasilkan, kami selalu menyesuaikan dengan selera konsumen serta kami berusaha melayani konsumen dengan baik. Dengan begitu, kami yakin perusahaan ini akan semakin maju serta semakin banyak konsumen yang berdatangan."

\footnotetext{
${ }^{5}$ Wawancara dengan pemilik perusahaan Ibu Nuratina Rahmawati, Tanggal 10 Mei 2020
}

${ }^{6}$ Wawancara dengan Karyawan Ainun Lyla, Tanggal 10 Mei 2020 
Dengan banyaknya konsumen yang berdatangan di konveksi ini, merupakan bukti bahwa perusahaan ini cukup mendapat keberhasilan dalam melakukan bisnis. Apalagi konsumen yang beli tidak hanya dari wilayah kabupaten Nganjuk, melainkan berasal dari luar kota seperti kota Blitar, Kota Malang, Kota Kediri, Kabupaten Trenggalek bahkan berasal dari luar pulau juga. Seperti halnya Pulau Kalimantan, Pulau Sumatra dan Pulau lain yang ada Di Indonesia. Sebagaimana yang telah dijelaskan oleh salah satu karyawan di Nuratina Collection: ${ }^{7}$ "Perusahaan ini bahkan terdapat konsumen yang ada di luar kota. Pengirimannya pun kadang sampai menggunakan ekspedisi cargo. Ini dikarenakan konsumen mengetahui kualitas produk perusahaan ini."

Semakin banyak konsumen semakin besar tantangan yang dihadapi oleh perusahaan ini. Seperti halnya, ketepatan waktu pengiriman pesanan yang dipesan oleh konsumen, ketelitian dalam mengerjakan barang yang dibeli oleh konsumen Karena jika mengalami keterlambatan dalam menyelesaikan barang yang dipesan konsumen serta terdapat kekeliruan dalam mengerjakan barang yang telah dipesan oleh konsumen (tidak sesuai dengan pesanan atau keinginan konsumen) maka kepercayaan konsumen terhadap perusahaan ini akan berkurang. Sebagaimana yang telah dijelaskan oleh salah satu karyawan di Nuratina Collection: ${ }^{8}$

"Tidak jarang perusahaan ini mendapat pesanan banyak dari konsumen. Hal ini selain mendatangkan keuntungan yang melimpah dari perusahaan akan tetapi juga merupakan tantangan yang cukup berat bagi perusahaan. Karena perusahaan harus benar-benar tepat waktu menyelesaikan barang yang dipesan oleh konsumen serta barang yang dikirim harus sesuai dengan keinginan konsumen sesuai dengan apa yang diinginkan konsumen"

Dalam mendapat konsumen yang banyak seperti yang telah didapatkan oleh perusahaan Nuratina Collection ini tidaklah diperoleh begitu saja. Tentunya perusahaan ini melakukan beberapa usaha untuk memasarkan barang hasil produksinya. Sehingga barang yang diproduksi diminati oleh masyarakat. Di samping itu perusahaan ini dikenal oleh banyak masyarakat. Hingga pada akhirnya perusahaan konveksi Nuratina Collection mendapat banyak konsumen. Seperti yang telah dijelaskan oleh salah satu karyawan: 9 "Saya pernah bertanya kepada konsumen dari mana mereka tahu tentang produk Nuratina Collection. Katanya mereka mengetahui dari teman-temannya yang seprofesi, dan menganjurkan untuk membeli dagangan di perusahaan ini."

Seperti halnya perusahaan lainnya, untuk menarik konsumen, perusahaan ini melakukan usaha promosi. Dengan promosi, maka perusahaan ini dapat dikenal oleh masyarakat sehingga barang hasil produksinya dapat laku terjual. Seperti yang telah dijelaskan oleh pengusaha Nuratina Collection: ${ }^{10}$ "Untuk mendapatkan konsumen yang semakin lama semakin banyak, kami melakukan usaha sebagaimana perusahaan lain lakukan. Yaitu melalui promosi. Promosi bagi kami merupakan hal penting yang harus dilakukan oleh perusahaan sehingga perusahaan tersebut dapat berhasil dan mendapatkan apa yang menjadi tujuan pokok perusahaan"

Hanya saja promosi yang dilakukan oleh perusahaan berbeda-beda. Adapun promosi yang dilakukan oleh Nuratina Collection pertama kali berdiri yaitu hanya sekedar melalui percakapan biasa kepada masyarakat. Hal itu tidaklah mudah dilakukan oleh perusahaan. Meskipun tidak membutuhkan dana yang banyak untuk melakukan promosi melalui percakapan secara langsung kepada masyarakat, pengusaha sering kali mendapat ujian dalam melakukan promosi seperti halnya tidak dihiraukan oleh masyarakat sekitar serta mendapat ejekan dari masyarakat. Akan tetapi hal tersebut tidaklah dihiraukan oleh pengusaha Nuratina Collection. Pengusaha perusahaan ini terus berusaha untuk melakukan promosi demi memperkenalkan barang hasil produksinya bersama beberapa orang karyawan.

\footnotetext{
${ }^{7}$ Wawancara dengan Karyawan Binti Nur Hidayah, Tanggal 10 Mei 2020

${ }^{8}$ Wawancara dengan Karyawan Mujiati, Tanggal 10 mei 2020

${ }^{9}$ Wawancara dengan Karyawan Binti Nur Hidayah, Tanggal 10 Mei 2020

${ }^{10}$ Wawancara dengan Pemilik Perusahaan Aulia Ibnu Romadhona, Tanggal 10 Mei 2020
} 
Pengusaha Nuratina Collection merupakan orang yang ulet, pantang menyerah dan tidak mudah putus asa. Sehingga dengan berbagai upaya yang dilakukan dapat membuahkan hasil yang cukup baik bagi perusahaan. Sebagaimana yang telah dijelaskan oleh salah satu karyawan di Nuratina Collection: ${ }^{11}$ "Ibu sosok pengusaha yang tidak mengenal kata putus asa, selain bekerja sebagai dokter ibu juga semangat dalam menjalankan usahanya. Beliau merupakan orang yang ulet dan selalu maksimal dalam melakukan pekerjaannya. Sehingga usaha yang didirikan berjalan dengan baik. Dan mendapat kepercayaan baik dari pembeli"

Sehingga dengan usaha yang dilakukan oleh pengusaha ini, konveksi ini semakin banyak memperoleh konsumen. Dan promosi secara langsung tidak dilakukan lagi oleh pengusaha. Bahkan saat ini pun pengusaha tidak pernah melakukan promosi sama sekali kepada masyarakat baik melalui lisan maupun tulisan atau selebaran. Akan tetapi secara tidak langsung melalukan pemasaran produk dengan cara Online dipasarkan di beberapa market place, karena di era sekarang ini masyarakat lebih sering melakukan suatu transaksi dengan cara Online, termasuk dalam hal belanja.

Meskipun promosi secara lisan tidak diberlakukan secara efektif seperti dulu, namun penjualan secara online bisa melebihi target yang telah ditetapkan. Sehingga, jika sepi konsumen yang memesan barang produksi konveksi ini, pengusaha memproduksi barang sendiri dan dipasarkan ke market place yang dapat dijangkau di seluruh negeri ini. Di situlah pengusaha juga melakukan pemasaran. Cara yang demikian berlanjut dan sering dilakukan mengingat banyak konsumen yang memesan dengan cara online. Sebagaimana yang telah dijelaskan oleh pengusaha Nuratina Collection.; 12 "Kami tidak melakukan promosi dalam bentuk apapun mengingat sudah cukup masyarakat tahu. Sehingga perusahaan ini dapat dikenal masyarakat dari mulut ke mulut. Sekalian disitu saya melakukan promosi secara online. Hanya saja cara demikian menjadi berkelanjutan saya lakukan hingga sekarang."

Sehingga dapat dikatakan bahwa perusahaan ini tidak melakukan usaha promosi secara langsung sebagaimana yang telah dilakukan oleh perusahaan lain. Perusahaan ini cukup melakukan promosi melalui media sosial yaitu menghasilkan pakaian yang sesuai dengan selera konsumen serta tidak mengecewakan konsumen.

\section{Kendala Pemasaran yang dihadapi Konveksi CV. Nuratina Collection Dalam Menghadapi Persaingan Bisnis di Era Industri 4.0}

Dalam melakukan strategi pemasaran tentunya ada kendala kendala yang dihadapi pemilik perusahaan dalam menjalankannya. Berikut pemaparan pemilik perusahaan mengenai kendala-kendala yang dihadapi:

\section{(1) Product (Produk)}

Dalam melakukan strategi pemasaran produk Nuratina Collection menemukan beberapa faktor penghambat. Pemaparan pemilik usaha mengenai faktor-faktor penghambat sebagai berikut:

Kendala Internal

"Ide, penghambat produk dari segi siklus hidup produk yang singkat. Apabila melakukan pemasaran produk dan produk berhasil terjual maka dengan cepat pesaing akan meniru. Dengan adanya pesaing yang meniru produk yang saya buat maka akan menghambat penjualan. Dalam membuat produk modal yang dibutuhkan sangat mahal. Sehingga proses produksi tidak boleh asal-asalan agar produk terjual dengan cepat dan perusahaan tidak mengalami kerugian."13

Kendala Eksternal:

\footnotetext{
${ }^{11}$ Wawancara dengan Karyawan Binti Nur Hidayah, Tanggal 12 mei 2020

${ }^{12}$ Wawancara dengan pemilik perusahaan Aulia Ibnu Romadhona, Tanggal 12 Mei 2020

${ }^{13}$ Wawancara dengan pemilik perusahaan Aulia Ibnu Romadhona, Tanggal 12 Mei 2020
} 
"Saya mempunyai ide untuk mencari tren baju melalui masukan dari karyawan untuk mencari lewat internet dengan melihat tren yang ada di Jakarta. Setelah saya mencoba membuatnya atau produksi, ternyata model yang dibuat kurang diminati oleh masyarakat. Dapat dikatakan bahwa untuk model-model baru ini di Nganjuk belum diminati karena kadang tren baju di Nganjuk ketinggalan dengan tren fashion dari kota-kota besar. Sehingga kekurangan ide untuk menciptakan produk yang sesuai dengan tren di daerah Nganjuk". ${ }^{14}$

Hasil wawancara dengan pemilik perusahaan tentang faktor penghambat dari produk yaitu dari kendala internal dari segi siklus hidup produk yang singkat. Apabila melakukan pemasaran produk dan produk berhasil terjual maka dengan cepat pesaing akan meniru. Dengan adanya pesaing yang meniru produk maka akan menghambat penjualan. Dalam membuat produk modal yang dibutuhkan sangat mahal. Sehingga proses produksi tidak boleh asal-asalan agar produk terjual dengan cepat dan perusahaan tidak mengalami kerugian. Untuk kendala eksternal dari produk untuk pengembangan produk hambatan yang dihadapi adalah kekurangan ide, maksudnya adalah kekurangan ide-ide produk baru yang akan dibuat, terkadang trend yang sudah ada di kota-kota besar belum bisa diterima oleh konsumen yang ada di Nganjuk, dengan kekurangan ide dapat membuat proses produksi tersendat dan konsumen juga akan bosan dengan produk yang kita jual apabila tidak dilakukan pengembangan produk.

Price (Harga)

Dalam bauran pemasaran harga terdapat faktor penghambat. Pemaparan pemilik perusahaan Nuratina Collection mengenai faktor-faktor penghambat harga sebagai berikut:

Kendala Internal:

"Penetapan harga sangat penting dalam penentuan usaha karena dapat sebagai penentu harga jual suatu produk. Akan tetapi kendala atau hambatan saya mengenai harga jika bahan baku dari pusat mengalami kenaikan harga. Maka saya akan menaikkan harga busana muslim atau seluruh produk saya yang bahan bakunya mengalami kenaikan harga, kepada semua konsumen. Akan tetapi sebagian besar konsumen menolak dengan kenaikan harga tersebut". ${ }^{15}$

Kendala Eksternal:

"Perusahaan saya mengalami kendala ketidakstabilan harga bahan-bahan impor dalam bahan baku". ${ }^{16}$

Hasil wawancara dengan pemilik perusahaan Nuratina Collection faktor penghambat harga dari segi internal yaitu penyesuaian harga pada hambatan yang dihadapi adalah kenaikan harga bahan baku dari pusat yang mengalami kenaikan sehingga pemilik usaha harus menaikkan harga produknya akan tetapi kebanyakan konsumen menolak dengan kenaikan harga tersebut. Sedangkan kendala eksternal yaitu perusahaan mengalami kendala dalam ketidakstabilan harga pada bahan baku import.

Promotion (Promosi)

Dalam bauran pemasaran promosi terdapat faktor penghambat. Pemaparan pemilik perusahaan Nuratina Collection mengenai faktor-faktor penghambat harga sebagai berikut,

\footnotetext{
${ }^{14}$ Wawancara dengan pemilik perusahaan Nuratina Rahmawati, Tanggal 12 Mei 2020

${ }^{15}$ Wawancara dengan pemilik perusahaan Aulia Ibnu Romadhona, Tanggal 12 Mei 2020

${ }^{16}$ Wawancara dengan pemilik perusahaan Nuratina Rahmawati, Tanggal 12 Mei 2020
} 
Kendala Internal:

"Perusahaan saya masih kekurangan karyawan yang memiliki kemampuan dan keahlian di bidang promosi dan pemasaran. Disamping itu sebagian karyawan tidak berasal dari latar belakang pendidikan yang sama"17

Kendala Eksternal:

"Kendala tentang promosi yaitu iklan, menurut saya iklan akan mengeluarkan biaya yang sangat besar misalnya iklan melalui, majalah, tabloid, surat kabar dan internet semua itu saya tidak mampu menjalankannya. Saat ini saya jalankan promosi menggunakan cara online dan harus mengeluarkan biaya yang cukup besar untuk iklan di sosial media". ${ }^{18}$

Hasil wawancara dengan pemilik perusahaan tentang faktor penghambat dari promosi yaitu dari segi internal terdapat hambatan kekurangan karyawan yang memiliki kemampuan di bidang promosi dan pemasaran selain itu sebagian karyawan tidak berasal dari pendidikan yang sama tentu saja menjadi kendala bagi perusahaan dalam mempromosikan hasil produksinya. Kendala dari segi eksternal yaitu biaya yang dikeluarkan untuk iklan melalui majalah, tabloid, dan surat kabar yang saat ini masih menjadikan penghambat perusahaan konveksi dalam memasarkan produknya. Untuk saat ini pemasaran yang dilakukan menggunakan online dengan website maupun facebook maupun market place.

Place (Tempat dan Saluran Distribusi)

Dalam bauran pemasaran place terdapat faktor penghambat. Pemaparan pemilik perusahaan Nuratina Collection mengenai faktor-faktor penghambat place/distribusi sebagai berikut,

Kendala Internal:

"Kendala selanjutnya adalah berkaitan dengan proses produksi dan pemasaran produk. Saya memproduksi model baru dengan bahan yang berberbeda dengan biasanya. Dengan bahan yang baru kendalanya kesulitan mencari pemasok kain yang saya inginkan sehingga proses produksi saya terhambat. Belum juga waktu distribusi barang yang baru, belum tentu semua konsumen saya berkenan dengan model dan bahan yang saya buat". ${ }^{19}$

\section{Kendala Eksternal}

"Mengalami komplain dari konsumen luar kota terkadang barang yang diterima oleh konsumen mengalami keterlambatan yang disebabkan oleh ekspedisi yang mengalami overload"20 $^{\prime 2}$

Hasil wawancara dengan pemilik perusahaan tentang faktor penghambat dari place atau distribusi dari segi internal yaitu pada saat memproduksi model baru dengan bahan yang berbeda dari biasanya maka kendala nya mencari pemasok bahan baku kain seperti yang dikehendaki perusahaan, keberadaan pemasok bahan baku yang belum ada maka dapat menghambat proses produksi yang ada. Pada saat distribusi barang baru ke konsumen belum tentu konsumen menyukai barang yang telah di produksi oleh perusahan

\footnotetext{
${ }^{17}$ Wawancara dengan pemilik perusahaan Aulia Ibnu Romadhona, Tanggal 12 Mei 2020

${ }^{18}$ Wawancara dengan pemilik perusahaan Aulia Ibnu Romadhona, Tanggal 12 Mei 2020

${ }^{19}$ Wawancara dengan pemilik perusahaan Aulia Ibnu Romadhona, Tanggal 12 Mei 2020

${ }^{20}$ Wawancara dengan pemilik perusahaan Aulia Ibnu Romadhona, Tanggal 12 Mei 2020
} 
konveksi CV. Nuratina Collection. Sedangkan dari segi eksternal terkadang barang yang diterima oleh konsumen mengalami keterlambatan pada ekspedisi.

\section{Pembahasan}

\section{Strategi Pemasaran Usaha Konveksi CV. Nuratina Collection Dalam Menghadapi Persaingan Bisnis di Era Industri 4.0}

Nuratina Collection merupakan salah satu konveksi yang ada di Kelurahan Bogo kecamatan Nganjuk Kabupaten Nganjuk. Perusahaan ini merupakan konveksi yang cukup maju dan pesat dalam perkembangan. Hal tersebut dapat dilihat dalam jumlah karyawan serta hasil pakaian.yang berasal dari beberapa wilayah khususnya di Kabupaten Nganjuk.

Seperti yang telah dijelaskan pada pembahasan sebelumnya bahwa tidak hanya satu jenis saja produk yang dihasilkan oleh Nuratina Collection, melainkan ada beberapa jenis produk yang dihasilkan oleh konveksi ini. Yaitu manset, baju muslimah, baju menyusui, Aksesoris dan produk-produk yang lain.

Adapun letak perusahaan ini sangat strategis sehingga mudah untuk dijangkau oleh para konsumen. Bahkan konsumen tidak hanya datang dalam kota saja, akan tetapi cukup banyak konsumen yang datang dari luar kota seperti halnya kota Kediri, Kota Blitar, kota Madiun, Kabupaten Tulungagung, Kabupaten Trenggalek dan masih banyak lagi. Bahkan konsumen yang berasal dari luar pulau pun juga ikut membeli produk yang dihasilkan oleh perusahaan ini.

Dengan banyaknya konsumen yang membeli, maka hal ini merupakan sesuatu yang sangat bagus dan mendukung Nuratina Collection untuk membuka reseller di kota-kota lain. Sehingga perusahaan lebih dikenal masyarakat dengan baik serta semakin banyak konsumen yang berdatangan. Tentunya dengan membuka reseller di kota lain, maka akan mengalami penambahan jumlah pendapatan di dalam perusahaan ini.

Tentunya perkembangan Nuratina Collection seperti saat ini, tidak dilakukan dengan cara yang mudah. Jatuh bangun pengusaha ini untuk melakukan pengembangan konveksi supaya konveksi ini lebih mengalami kemajuan. Akan tetapi, pengusaha Nuratina Collection menggunakan kegagalan yang dialami tersebut sebagai cambuk bagi dirinya untuk tetap berusaha demi mendapatkan sesuatu yang maksimal.

Begitupun dengan banyaknya konsumen yang ada sekarang. Yang pasti banyaknya konsumen yang belanja seperti sekarang ini, tidak didapatkan begitu saja oleh Nuratina Collection. Dengan mengeluarkan produk yang sesuai dengan selera konsumen serta pelayanan yang baik merupakan usaha yang paling penting untuk dilakukan oleh konveksi ini.

Semakin banyak konsumen semakin besar tantangan yang dihadapi oleh perusahaan ini. Seperti halnya, ketepatan waktu penyelesaian pesanan yang dipesan oleh konsumen, ketelitian dalam mengerjakan barang yang dipesan oleh konsumen Karena jika mengalami keterlambatan dalam menyelesaikan barang yang dipesan konsumen serta terdapat kekeliriuan dalam mengerjakan barang yang telah dipesan oleh konsumen (tidak sesuai dengan pesanan atau keinginan konsumen) maka kepercayaan konsumen terhadap perusahaan ini akan berkurang.

Dalam mendapat konsumen yang banyak seperti yang telah didapatkan oleh perusahaan Nuratina Collection ini tidaklah diperoleh begitu saja. Tentunya perusahaan ini melakukan beberapa usaha untuk memasarkan barang hasil produksinya. Sehingga barang yang diproduksi diminati oleh masyarakat. Disamping itu perusahaan ini dikenal oleh banyak masyarakat. Hingga pada akhirnya perusahaan konveksi Nuratina Collection mendapat banyak konsumen.

Seperti halnya perusahaan lainnya, untuk menarik konsumen, perusahaan ini melakukan usaha promosi. Dengan promosi, maka perusahaan ini dapat dikenal oleh masyarakat sehingga barang hasil produksinya dapat laku terjual. Hanya saja promosi yang dilakukan oleh perusahaan berbeda-beda. Adapun promosi yang dilakukan oleh Nuratina Collection pertama 
kali berdiri yaitu hanya sekedar melalui percakapan biasa kepada masyarakat. Hal itu tidaklah mudah dilakukan oleh perusahaan. Meskipun tidak membutuhkan dana yang banyak untuk melakukan promosi melalui percakapan secara langsung kepada masyarakat, pengusaha sering kali mendapat ujian dalam melakukian promosi seperti halnya tidak dihiraukan oleh masyarakat sekitar serta mendapat ejekan dari masyarakat. Akan tetapi hal tersebut tidaklah dihiraukan oleh penguasaha Nuratina Collection. Pengusaha perusahaan ini terus berusaha untuk melakukan promosi demi memperkenalkan barang hasil produksinya bersama beberapa orang karyawan.

Pengusaha Nuratina Collection merupakan orang yang ulet, pantang menyerah dan tidak mudah putus asa. Sehingga dengan berbagai upaya yang dilakukan dapat membuahkan hasil yang cukup baik bagi perusahaan. Dengan usaha yang dilakukan oleh pengusaha konveksi ini, konveksi ini semakin banyak memperoleh konsumen. Dan promosi secara langsung tidak dilakukan lagi oleh pengusaha. Bahkan saat ini pun pengusaha tidak pernah melakukan promosi sama sekali kepada masyarakat baik melalui lisan maupun tulisan atau selebaran. Akan tetapi secara tidak langsung para konsumen yang datang untuk membeli barang hasil produksi perusahaan konveksi ini melakukan promosi. Sehingga konsumen menceritakan secara langsung kepada masyarakat dimanakah ia memesan pakaian yang hendak dibelinya.

Meskipun promosi secara lisan tidak diberlakukan secara efektif seperti dulu, perusahaan ini terutama pengusaha melakukan promosi secara online. Sehingga, jika sepi konsumen yang membeli barang secara offline, bisa membeli memalui online yang tersebar diberbagai Market Place di seluruh Indonesia bahkan bisa sampai ke manca Negara. pengusaha memproduksi barang sendiri dan dipasarkan di berbagai media yang tersebar di Indonesia. Dapat dikatakan bahwa perusahaan ini tidak melakukan pemasaran secara tidak langsung sebagaimana yang tidak dilakukan oleh perusahaan lain. Kalau Perusahaan konveksi lainnya biasanya melalukan pemasaran secara langsung face to face atau door to door tetapi lain dengan perusahaan ini, perusahaan ini cukup bagus dalam hal melakukan pemasaran online, sehingga menarik minat pelanggan dari luar kota bahkan luar pulau. Perusahaan ini cukup melakukan pemasaran melalui usaha perusahaan itu sendiri yaitu menghasilkan pakaian yang sesuai dengan selera konsumen serta tidak mengecewakan konsumen.

Di era industri 4.0 kita harus bisa mengenal dunia digital lebih dalam. Apa itu Era Industri 4.0? Istilah Industri 4.0 lahir dari ide tentang revolusi industri keempat. Keberadaannya menawarkan banyak potensi manfaat. Istilah Industri 4.0 sendiri secara resmi lahir di Jerman tepatnya saat diadakan Hannover Fair pada tahun 2011 (Kagermann dkk, 2011). Negara Jerman memiliki kepentingan yang besar terkait hal ini karena Industri 4.0 menjadi bagian dari kebijakan rencana pembangunannya yang disebut High-Tech Strategy 2020. Kebijakan tersebut bertujuan untuk mempertahan-kan Jerman agar selalu menjadi yang terdepan dalam dunia manufaktur. Beberapa negara lain juga turut serta dalam mewujudkan konsep Industri 4.0 namun menggunakan istilah yang berbeda seperti Smart Factories, Industrial Internet of Things, Smart Industry, atau Advanced Manufacturing. Meski memiliki penyebutan istilah yang berbeda, semuanya memiliki tujuan yang sama yaitu untuk meningkatkan daya saing industri tiap negara dalam menghadapi pasar global yang sangat dinamis. Kondisi tersebut diakibatkan oleh pesatnya perkembangan pemanfataan teknologi digital di berbagai bidang.

Di Indonesia Sendiri sudah memasuki era industri 4.0, dimana dunia teknologi berkembang sangat baik. Seiring bertambahnya waktu manusia tergantung pada teknologi dan dituntut menguasai teknologi modern sehingga tidak dianggap kurang uptade mengenai dunia masa kini dan masa mendatang. Dalam perusahaan ini proses pemasaran menggunakan industri 4.0 yaitu dengan teknologi yang berkembang sekarang ini. Melalui media online sangat efektif untuk pemasaran dalam berjualan karena manusia sendiri sekarang lebih memilih menggunakan sesuatu bahkan berbelanja dengan cara online. Sehingga dapat menghemat tenaga dan waktu, apalagi dengan orang yang berkarir yang harus pandai-pandai mengatur waktu. Cara ini sangat efisiean dan mengguntungkan pihak yang berkarir atau bahkan pihak yang lainya juga. 
Di dalam Islam Jual beli online (salam) diperbolehkan asalkan sesuai dengan syariat Islam dan tidak menipu konsumen dengan apa yang telah diposting di sosial media. Menurut saya konveksi ini telah memenuhi syariat agama islam mengenai pemasaran yang melibatkan akad salam. Dari beberapa penjelasan terkait dengan praktik pemasaran yang dilakukan oleh Nuratina Collection, perusahaan ini menggunakan pemasaran dengan cara Online sesuai dengan Era Industri 4.0 sekarang. Mengingat terdapat beberapa cara yang dilakukan oleh perusahaan yaitu:

\section{(1) Melakukan pemasaran di media sosial.}

Memanfaatkan media sosial di era digital saat ini dapat memberikan potensi yang besar dalam rangka pemasaran dan periklanan produk atau layanan jasa keuangan. Berdasarkan data yang didapat dari "Indonesia Digital Landscape 2018" We Are Social sebesar 130 juta lebih dari total penduduk Indonesia merupakan pengguna aktif media sosial. Jumlah pengguna sebesar ini tentunya memberikan potensi besar bagi periklanan suatu produk dan layanan jasa keuangan. Penggunaan media sosial dalam rangka pemasaran produk dan layanan jasa keuangan dapat bersifat masif dan menjangkau masyarakat lebih banyak. Selain memiliki potensi jumlah penguna tersebut, media sosial memiliki manfaat lainnya yaitu dapat digunakan untuk berinteraksi dengan konsumen secara lebih dekat dibandingkan dengan strategi pemasaran melalui media tradisional. Dengan menggunakan media sosial dalam strategi pemasaran dan periklanan produk, pemilik usaha dipermudah dalam mendapatkan feedback langsung dari konsumen dan masyarakat terkait produk dan layanan yang ditawarkan. Sehingga dapat dikatakan bahwa melalui penggunaan media sosial, upaya dan aktivitas periklanan bukan lagi sesuatu yang bersifat pasif, namun lebih kepada upaya yang interaktif. Sebenarnya di Media sosial cara pemasarannya cukup mudah tinggal posting gambar-gambar yang sudah diambil dari perusahaan. Perusahaan ini melakukan pemasaran di media sosial antara lain:

a) Fanpage, salah satu sosial media yang digunakan untuk pemasaran yaitu fanpage, di fanpage kita bisa menjual hasil produksi perusahaan dengan cara share gambar dan keterangan detailnya.

b) Instagram, di Instagram cara pemasarannya sama seperti di fanpage dengan share gambar dan keterangan detailnya.

c) Telegram, ditelegram bahkan lebih mudah kita melakukan pemasaran karena pembeli bisa mengambil gambar secara langsung dari telegram.

d) WhatsApp, beda cara pemasaran dengan media sosial lainnya WhatsApp pada perusahaan ini lebih melayani pembeli yang tahu produk perusahaan dari pemasaran di Fanpage, Instagram dan Telegram.

\section{(2) Melalui Market Place.}

Perusahaan ini melakukan pemasaran melalui market place juga, selain mempermudah pemasaran juga menghemat tenaga pembeli agar mudah belanja dimanapun berada. Perusahaan ini menggunakan beberapa Market Place diantaranya:

a) Shopee, merupakan salah satu market place terbesar yang banyak diminati pembeli karena program voucher gratis ongkir yg bekerja sama dengan pihak ekspedisi. Selain mempermudah penjualan dan pemasaran shopee juga mempermudah pembeli untuk belanja barang dan bisa membayar belanjaan ketika barang sudah sampai ke pembeli.

b) Bukalapak, di Bukalapak juga salah satu market place yang digunakan untuk pemasaran oleh perusahaan ini. Dalam market place ini banyak diskon yang ditawarkan oleh penjual untuk menarik minat pembeli. 
c) Tokopedia, tokopedia atau lebih dikenal dengan nama toped juga merupakan salah satu market place yang digunakan, meskipun tidak terlalu banyak minat masyarakat dengan market place ini.

d) Lazada, merupakan salah satu tempat pemasaran yang cukup bersaing dengan shopee karena banyak diminati masyarakat. Promo dan diskon yang menarik hampir selalu jadi andalan pada market place ini.

Pemasaran tersebut dilakukan secara efektif pada perusahaan hingga sekarang ini. Promosi secara lisan sudah tidak dilakukan lagi. Sehingga masyarakat mengetahui produk perusahaan ini hanya dari media sosial atau market place. Apalagi di era sekarang yang serba Instan menggunakan teknologi modern, banyak orang-orang yang belanja dengan cara online. Selain menghemat waktu juga menghemat tenaga dengan cara belanja online.

Strategi Promosi Perusahaan sering digunakan sebagai salah satu cara untuk meningkatkan penjualan barang ditawarkan, sehingga dapat meningkatkan laba yang diperoleh. Selain itu kegiatan promosi juga memberikan kemudahan dalam merencanakan strategi pemasaran selanjutnya, karena biasanya kegiatan promosi dijadikan sebagai cara berkomunikasi langsung dengan calon konsumen. Sehingga kita dapat memperoleh informasi akurat dari para konsumen, mengenai respon produk yang kita tawarkan.

\section{Kendala Strategi Pemasaran Dalam Menghadapi Persaingan Bisnis di Era Industri 4.0}

Strategi pemasaran adalah sesuatu yang melingkupi semua sistem yang memiliki hubungan dengan tujuan untuk merencanakan dan menentukan harga hingga mempromosikan dan menyalurkan produk (barang atau jasa) yang dapat memuaskan konsumen. Didalam dunia bisnis melakukan strategi pemasaran pasti ada kendala-kendala yang dihadapi pemilik perusahaan dalam menjalankannya. Apalagi di Era Industri 4.0 sekarang ini banyak kendala yang dihadapi oleh pemilik usaha. Dari wawancara sebelumnya dapat ditemukan beberapa kendala yang dihadapi perusahaan ini. Berikut ini kendala- kendala yang dihadapi:

(1) Produk

Dalam melakukan stretegi pemasaran produk kendala yang dihadapi pemilik yaitu siklus hidup produk yang singkat. Apabila perusahaan berhasil melakukan pemasaran produk dan terjual sangat cepat maka para pesaing bisnis dari luar akan meniru produk. Dengan adanya pesaing yang meniru produk dari hasil perusahaan maka akan menghambat jalannya penjualan.

Ide membuat pakaian yang lagi tren di kota kota-besar, setelah melihat dan mencoba membuat pakaian yang lagi tren justru model tersebut dapat dikatakan belum diminati warga lokal atau daerah-daerah terpecil yang ketinggal dengan tren dikota-kota besar, sehingga pemilik perusahaan kekurangan ide untuk menciptakan produk-produk yang bisa diterima warga Nganjuk.

(2) Harga

Penetapan harga sangat penting dalam penentuan usaha karena sebagai penentu harga jual produk. Jika bahan yang didapat dari pusat mengalami kenaikan harga maka harga hasil produk juga akan mengalami kenaikan,.ketidak stabilan harga bahan baku dari pusat membuat harga produk yang dibuat juga melejit, sehingga kebanyakan konsumen menolak kenaikan harga tersebut.

(3) Promosi

Kendala yang dialami perusahaan dalam melakukan promosi yaitu kurangnya karyawan yang memiliki kemampuan dan keahlian di bidang promosi dan pemasaran, 
karena sebagian karyawan tidak berasal dari latar belakang pendidikan yang sama. Selain itu promosi melalui media soaial dan market place juga membutuhkan biaya yang cukup besar untuk Iklan tersebut.

\section{Tempat atau Saluran Distribusi}

Faktor atau kendala penghambat tempat atau saluran distribusi ini bahan yang berbeda dengan bahan biasanya digunakan. Dengan adanya bahan yang baru kesulitan mencari pemasok kain yang diinginkan pemilik sehingga proses produksi terlambat. Selanjutnya adanya komplen dari konsumen luar kota atau luar pulau yang terkadang adanya keterlambatan barang diterima disebabkan oleh pihak ekspedisi yang mengalami overload.

\section{Sumber Daya Manusia (SDM)}

Mengenai upaya peningkatan kompetensi dan produktivitas SDM, perlu dilakukan pemerintah upaya yaitu pelatihan kerja, badan setifikasi yang dilakukan pemerintah melalui pelatihan di Balai Latihan Kerja dan program-program digital. Masalah-masalah yang terjadi pada hari ini, tidak dapat diselesaikan dengan cara-cara sama seperti dalam konsep yang lampau tentu harus bisa menyesuaikan masa sekarang atau sesuai kebutuhan di era industri 4.0. Revolusi Indsutri 4.0 tidak mungkin hanya dihadapi dengan pengembangan teknologi tanpa melibatkan SDM di dalamnya. Karena SDM adalah pelaku dalam industri 4.0 .

Selain itu kendala yang sangat dominan yaitu SDM yang kurang mumpuni dalam bidang teknologi. Upaya meningkatkan kompetensi dan kemampuan SDM di era revolusi industri 4.0 merupakan tantangan terbesar yang harus dihadapi oleh dunia usaha. Karena, tidak sedikit kompentensi SDM yang kini tak lagi sesuai dengan kebutuhan industri.

Terlepas dari banyaknya kendala yang dialami dalam perusahaan baik kendala dari dalam maupun kendala dari luar, pengusaha tetap teguh dan semangat menjalankan bisnisnya hingga sukses seperti sekarang ini.

\section{KESIMPULAN}

Untuk mencapai tujuan seperti yang diinginkan dan menjawab rumusan masalah dalam penelitian ini berdasarkan hasil analisis data, pengolahan data, maka dapat disimpulkan bahwa:

a. Dari pembahasan yang sudah diuraikan, maka dapat disimpulkan bahwa dalam melakukan kegiatan promosi di awal berdirinya konveksi, pengusaha melakukannya dengan cara lisan atau langsung terjun dalam masyarakat untuk memasarkan produk yang dihasilkan. Hal ini sesuai dengan hasil wawancara yang dilakukan peneliti terhadap pemilik konveksi. Akan tetapi setelah perusahaan mengalami kemajuan strategi promosi yang dilakukan dari lisan tersebut tidak dilakukan dengan efektif. Pemilik konveksi melakukan pemasaran produknya melalui sosial media dan market place dengan menyuguhkan gambar produksinya yang dikemas dengan menarik. Sehingga masyarakat mengetahui perusahaan ini dan akhirnya mengkonsumsi barang produksi dari perusahaan ini berasal dari informasi orang lain yaitu orang yang pernah mengkonsumsi barang dari perusahaan ini. Hal ini sesuai dengan teori Itami yang mana dalam teorinya disebutkan bahwa Strategi menentukan kerangka kerja dari aktivitas bisnis perusahaan dan memberikan pedoman untuk mengkoordinasikan aktivitas sehingga Perusahaan dapat menyesuaikan dan mempengaruhi lingkungan yang selalu berubah.

b. Kendala strategi pemasaran dalam pembahasan diatas sudah disebutkan bahwa ada beberapa faktor penghambat yang dialami pengusaha dalam menjalankan bisnisnya. Di antaranya yaitu siklus hidup produk yang singkat, banyak pengusaha lain yang meniru produk best seller 
sehingga menghambat penjualan. Ide tren baju dikota-kota besar yang tidak bisa diterima daerah-daerah pelosok atau desa. Penetapan harga yang berbeda untuk harga jual produk karena adanya kenaikan harga bahan dari pabrik pusat. Kuranganya karyawan yang memiliki kemampuan dan keahlian dibidang pemasaran karena tidak berasal dari latar belakang pendidikan yang sama. Biaya iklan di media sosial dan market place yang cukup besar untuk promosi. Model baru tapi bahan berdeda dengan sebelumnya sulit untuk mencari pemasok bahan baku yang diinginkan pengusaha. Keterlambatan pengiriman dari pihak ekspedisi karena overload atau tanggal merah serta kurangnya SDM yang bisa mengusai teknologi di era industri 4.0 seperti sekarang ini.

\section{UCAPAN TERIMA KASIH}

Untuk dapat menyelesaikan penelitian ini, penulis mendapatkan berbagai bantuan dari beberapa pihak. Oleh karena itu penulis berkewajiban menyampaikan rasa terima kasih sedalam-dalamnya, terutama kepada: Rektor Institut Agama Islam Pangeran Diponegoro (IAI PD) Nganjuk yang telah memberikan izin kepada penulis untuk dapat menyelesaikan studi akhir. Dekan Fakultas Syariah dan Ekonomi Islam, yang telah memberikan izin dan pengarahan pada peneliti.

\section{DAFTAR RUJUKAN}

Abdul Manan, Hukum Ekonomi Syariah. Jakarta: Kencana, 2014.

Anis fuad \& Kandung Sapto Nugroho, panduaan Praktis Penelitian Kualitatif, Yogyakarta: Graha ilmu, 2014.

Ika Yunia Fauzia, Etia Bisnis Dalam Islam edisi pertama. Jakarta: Kenca Prenada Media Group, 2013.

Kasmir, Kewirausahaan. Jakarta: PT Raja Grafindo Persada cetakan ke 7, 2012.

Sudaryono, Metodologi Penelitian. Jakarta: Rajawali Pers, 2017. 